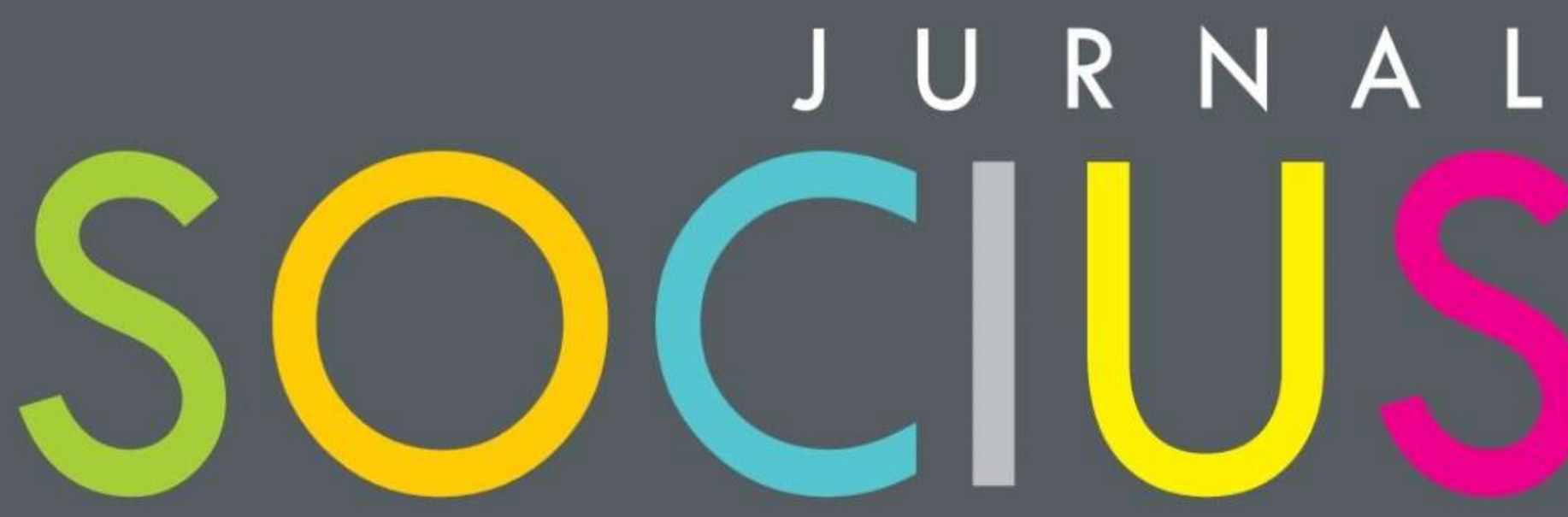

Journal of Sociology Research and Education

DITERBITKAN OLEH :

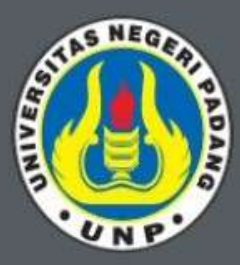

LABOR JURUSAN SOSIOLOGI FAKULTAS ILMU SOSIAL UNIVERSITAS NEGERI PADANG

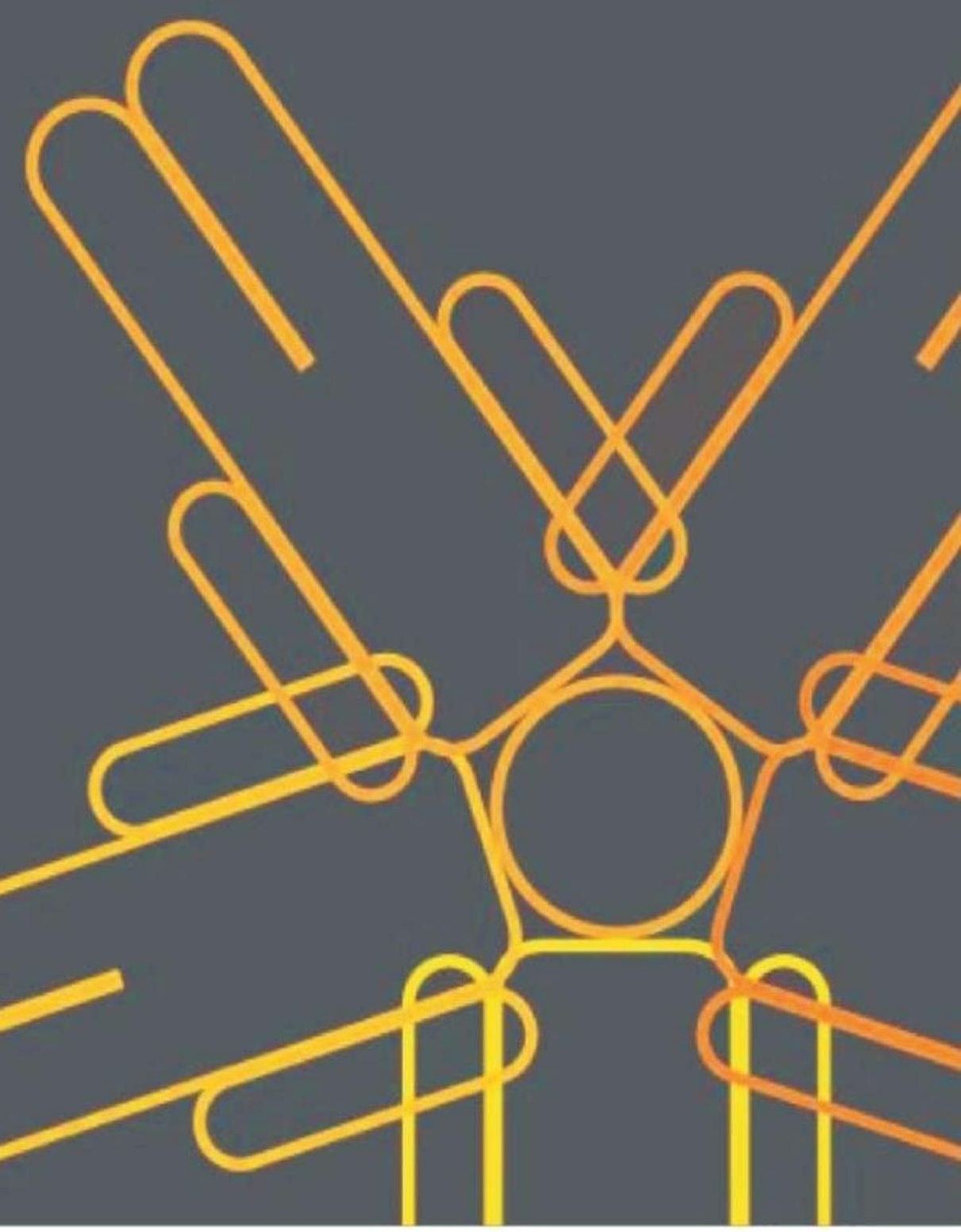




\section{SOCIUS}

Vol. 4, No.1, Th. 2017

ISSN: 2356-4180 (cetak)

2442-8663 (online)

REDAKSI JURNAL SOCIUS

Ketua Dewan Penyunting : Dr. Erianjoni, S.Sos., M.Si

Wakil Ketua Dewan Penyunting : Selinaswati, S.Sos., M.A., Ph.D.

\section{Dewan Penasehat:} Prof. Dr. Syafri Anwar, M.Pd (Universitas Negeri Padang) Prof. Dr. Mestika Zed, MA. (Universitas Negeri Padang) Prof. Dasman Lanin, M.Pd., Ph. D. (Universitas Negeri Padang) Bakhrul Khair Amal, SE.,M.Si. (Universitas Negeri Medan)

Prof. Dr. Ferdinand Kerebungu, M.Si. (Universitas Negeri Manado) Dr.rer.nat. Nurhadi, S.Ant., M. Hum. (Universitas Negeri Solo)

Drs. Emizal Amri, M.Pd., M.Si. (Universitas Negeri Padang) Adri Febrianto, S.Sos., M.Si. (Universitas Negeri Padang) Drs. Ikhwan, M.Si. (Universitas Negeri Padang)

Dewan Penyunting:

Dr. EkaVidya Putra,S.Sos,.M.Si. Dr. Desy Mardiah,S.Sos.,S.Thi,.M.Si Ike Sylvia, S.IP,.M.Si

M. Isa Gautama,S.Pd,.M.Si. Reno Fernandes, S.Pd.,M.Pd.

\section{Layout Editor:}

Rhavy Ferdyan, S.Pd.

Technical Support:

Rudi Mahesa, A.Md.

Alamat Redaksi:

Jurusan Sosiologi FIS UNP

Jl. Prof.Dr.Hamka

Kampus UNP Air Tawar

e-mail: sosan@fis.unp.ac.id

\section{Penerbit}

Labor Jurusan Sosiologi

Universitas Negeri Padang
Artikel :

\section{DAFTAR ISI}

\section{Eka Vidya Putra}

Money Politics Dalam Penyelengaran Pemilihan Umum

Di Kota Pariaman

Halaman 1-16

Helpi Nelwatri

Upaya Preventif Masalah Kesehatan Reproduksi Remaja Melalui Media Informatif Buku Saku Kespro

Berbasis Budaya Lokal Untuk Orang Tua

Di Kabupaten Lima Puluh Kota

Provinsi Sumatera Barat

Halaman 17-21

\section{Junaidi}

Upaya Meningkatkan Kemampuan Peserta Didik Berpikir Kritis

Melalui Penerapan Srategi Pembelajaran Berbasis Masalah

Pada Pembelajaran Sosiologi Kelas XI IPS 2 SMA Negeri 1 Pariaman Halaman 22-30

Muhammad Hidayat

Problematika Internal Nelayan Tradisional KotaPadang:Studi FaktorFaktor Sosial Budaya Penyebab Kemiskinan

$$
\text { Halaman 31-40 }
$$

Mohammad Isa Gautama

Analisis Framing Pemberitaan Operasi Tangkap Tangan Patrialis Akbar

Di Media Daring Lokal Dan Nasional Halaman 41-49

\section{Nurlizawati}

Perceraian Secara Adat (Cerai Dusun)

Halaman 50-60 


\title{
UPAYA PREVENTIF MASALAH KESEHATAN REPRODUKSI REMAJA MELALUI MEDIA INFORMATIF BUKU SAKU KESPRO BERBASIS BUDAYA LOKAL UNTUK ORANG TUA DI KABUPATEN LIMA PULUH KOTA PROVINSI SUMATERA BARAT
}

\author{
Helpi Nelwatri
}

\author{
Poltekkes Kemenkes RI Padang \\ Email: helpielep@yahoo.co.id
}

\begin{abstract}
Abstrak
Artikel ini merupakan hasil penelitian yang dilatarbelakangi oleh randahnya pengetahuan remaja tentang kesehatan reproduksi. Salah satu faktor penyebab rendahnya pengetahuan remaja tersebut adalah karena kurangnya keterlibatan orang tua dalan upaya preventif mencegah masalah kesehatan reproduksi remaja di Kabupaten Lima Puluh Kota. Maka perlu buku panduan kesehatan reproduksi untuk orang tua dengan pendekatan budaya. Penelitian ini dilakukan dengan metode pengembangan (Research and Development), yaitu metode penelitian yang digunakan untuk menghasilkan suatu produk tertentu, dan menguji keefektifan produk tersebut. Hasil penelitian: Sumber informasi tentang kesehatan reproduksi remaja di Kabupaten Lima Puluh Kota adalah dari orang terdekat, penyuluhan kesehatan dan kader posyandu, serta media massa. Peran orang tua dalam memberikan informasi kesehatan reproduksi remaja tersebut di Kabupaten Lima Puluh Kota adalah berperan sebagai pemberi informasi pertama dan mengawasi perkembangan kesehatan reproduksi anak. Strategi preventif untuk memberikan informasi kesehatan reproduksi pada remaja dalam mengatasi masalah kesehatan reproduksi, yaitu dengan cara pendidikan kesehatan reproduksi oleh orang tua menggunakan buku saku kesehatan reproduksi untuk orang tua berbasis budaya lokal.
\end{abstract}

Kata kunci: Upaya preventif, Kesehatan reproduksi remaja, Media informatif buku saku

Abstract

This article discusses the less knowledge of adolescent about reproduction health issues and the role of their parents to give them such that information. The research is conducted at Lima Puluh Kota Regency, West Sumatera. One ofthefactors that affect their knowledge is a small contribution of their parents in preventing the reproduction health problem. The research uses Research and Development method. The result showed that the source of adolescent information about reproduction health comes from the closest one, health educator, cadre of posyandu, and mass media. As parents have a function to socialize and first informants for their children, including about reproductive health and controlling the development of their reproduction health, the preventive strategy is giving the parent some information about reproductive health to prevent their kids from reproduction health problem by using reproduction health booklet for parent base on local culture.Thus, it is important for parents to have a booklet of reproduction health with local culture approach.

Keywords: Prevention effort, Adolescent reproduction health, Booklet information

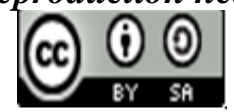

Received: January 31, 2017

Revised: April 14, 2017

Available Online: June 22, 2017

Jurnal Socins: Journal of Sociology Research and Education Vol. 4, No.1, Th. 2017

ISSN: Online 2442-8663 - Print 2356-4180 


\section{Pendahuluan}

Masa remaja merupakan suatu masa yang dinamakan masa peralihan atau transisi dari masa anak-anak ke masa kehidupan dewasa. Pada masa ini seorang remaja akan sering diliputi oleh masalah ketidaktahuan mereka tentang perkembangan diri mereka yang bisa menimbulkan berbagai problema. Problematika yang sering mereka hadapi, umumnya bersumber karena kurangnya informasi yang mereka peroleh tentang perubahan dalam diri mereka khususnya yang berhubungan dengan masalah kesehatan reproduksi. Secara spesifik kesehatan reproduksi memang mereka peroleh melalui pembelajaran di sekolah sebagai internal dari suatu kurikulum. Sedangkan ketika mereka di rumah dan di lingkungan tempat tinggalnya, mereka juga tidak banyak mendapattkan informasi yang terbuka mengenai hal-hal yang behubungan dengan masalah kesehatan reproduksi secara tepat dan benar. Berdasarkan hasil survey yang telah dilakukan oleh lembaga IRRMA pada lima Propinsi di Pulau Sumatera (yaitu: Sumatera Utara, Sumatera Barat, Jambi, dan Lampung serta Bengkulu) terhadap bagaimnan tingkat pengetahuan, sikap dan perilaku seksual remaja pada tahun 2003, dari sampling 1.450 remaja yang telah menjadi responden, ternyata sebanyak $22,36 \%$ telah pernah melakukan hubungan seksual sejak mereka usia 16 tahun untuk remajaberjenis kelamin perempuan dan 17 tahun untuk remaja berjenis kelamin laki-laki. Pada kasus remaja yang aktif melakukan aktivitas hubungan seksua bebas, ditemukan sebanyak 19,70\% telah melakukannya dengan PSK dan sebanyak 79,30\% dengan pacar mereka sendiri. Dari data sebagian besar $(86,87 \%)$ dari remaja yang melakukan ktivitas seksual aktif ternyata mereka tidak memiliki pengetahuan sedikitpun tentang masalah kesehatan reproduksi, sedangkan sisanya, pengetahuan mereka hanya terbatas sekali, yang hanya mereka dapatkan dari teman sebaya atau melalui media massa (Saeroni, 2008). Di Jakarta, hasil survei Boy dan kawankawan terhadap 1.400 siswi pada 1-30 Mei 2007 dinyatakan, bahwa siswi SMU hanya tahu informasi seputar seksual hanya dari teman (69\%), dari informai orangtua (14\%) dari pengajaran di sekolah (13\%) dan dari sang pacar (4\%). Temuan lain menunjukkan bahwa dalam riset itu bagaimana pemahaman siswi Jakarta tentang konsep keperawanan. Para siswi SMU Jakarta menyatakan bahwa konsep keperawanan dianggap masih penting. Sehingga akibat hilangnya keperawanan, berarti akan kehilangan pula masa depan mereka (63\%). Selanjutnya, akibat hilangnya sebuah keperawanan, akan membuat "hidup enggan mati tak mau" yaitu sebanyak 23\%. Terdapat sebanyak 6\% siswi menyatakan mereka mengikuit trend. Hanya $6 \%$ saja dari mereka yang menilai bahwa sebuah keperawanan itu hanyalah simbol belaka, dan yang lainnya hanya sebesar $8 \%$ saja (Saputra, 2008).

Komisi Nasional Perlindungan Anak yang melakukan survei terhadap 4.726 siswi SLTP dan SMA tahun 2008. Pada 33 provinsi di Indonesia, menunjukkan bahwa sejumlah 62,7\% siswi dari responden mengaku sudah tidak perawan lagi (Prasasti dan Ririn Indriani, 2009). Di Provinsi Sumatera Barat, khususnya beberapa kasus yang terjadi di Kabupaten Lima Puluh Kota yang diperoleh Berdasarkan data dari daerah Kabupaten Lima Puluh Kota, ditemukan tiga orang remaja putri tingkat pendidikan SLTA yang tidak mengikuti kegiatan Ujian Nasional (UN) pada tahun 2014 karena mereka sedang hamil kaibat hubngan seksul di luar nikah. Setelah adanya penelusuran, ternyata ketiga remaja tersebut ada di wilayah Selatan Kabupaten 50 kota, mereka itu hamil akibat aktivitas "Arisan Seks". Modusnya hampr sama dengan sebuah arisan biasa, mereka membuat komunitas sendiri, lalu mereka menggelar pertemuan, dan mengadakan proses undian serta mereka mencabut sebuat loting (www.Padangekspres.co.id Diakses tanggal 14 Mei 2014). Untuk itu berdasarkan data dan rasional masalah serta penelitian terdahulu di atas, maka peneliti tertarik meneliti tentang "Upaya Preventif Masalah Kesehatan Reproduksi Remaja Melalui Media Informatif Buku

Jurnal Socius: Journal of Sociology Research and Education Vol. 4, No.1, Th. 2017 
Saku Kespro Berbasis Budaya Lokal untuk Orang Tua di Kabupaten Lima Puluh Kota Provinsi Sumatera Barat"

\section{Metode Penelitian}

Penelitian ini merupakan Penelitian pengembangan (Research and Development) yang merupakan metode penelitian yang dilakukan untuk menghasilkan sebuah produk tertentu, dan menguji apakah keefektifan produk yang dihasilkan tersebut. Penelitian ini telah dilaksanakan selama tiga bulan, yaitu mulai dari bulan Mei sampai bulan Juli tahun 2016 yang lalu. Pelaksanaan penelitian dilakukan di Kabupaten Lima Puluh Kota Provinsi Sumatera Barat, dengan memilih Nagari Situjuh Banda Dalam. Teknik pemilihan informan dalam penelitian ini yang peneliti lakukan adalah teknik purposive sampling (penarikan sampel secara sengaja). Adapun informan penelitian ini adalah orang tua yang memiliki anak pada usia remaja, remaja, bidan, tokoh adat, guru, dinas kesehatan dan pihak BKKBN. Teknik pengumpulan data dalam penelitian ini adalah observasi (pengamatan), wawancara terstruktur, dan studi dokumen serta melalui Focus Group Discussion (FGD). Data yang diperoleh dianalisis dengan menggunakan analisis taksonomi dari James Spradley.

\section{Hasil Dan Pembahasan}

Dari studi lapangan yang telah dilakukan oleh tim peneliti ke lokasi penelitian, telah diperoleh data untuk menjawab permasalahan penelitian. Adapun upaya preventif dalam rangka mencegah masalah kesehatan reproduksi oleh orang tua di Nagari Situjuah Banda Dalam yang merupakan bagian dari Kecamatan Limo Nagari Kabupaten Lima Puluh Kota, dapat dipolakan ke dalam pola berikut ini, yaitu:

\section{Sumber informasi tentang kesehatan reproduksi remaja di Kabupaten Lima Puluh Kota}

\section{Orang terdekat}

Informasi yang diperoleh para orang tua khususnya ibu tentang kesehatan reproduksi remaja umumnya berasal dari sosialiasi dari (1) ibu/ nenek ketika masih remaja dulu, (2) tetangga serta (3) diskusi dengan teman sejawat di waktu-waktu luang.

\section{Penyuluhan Kesehatan dari Tenaga Kesehatan dan Kader Posyandu}

Selain dari informasi dari orang terdekat, pengetahuan tentang seputar kesehatan repoduksi remaja, juga diperoleh oleh orang tua dari para petugas kesehatan termasuk para kader Posyandu, melalui kegiatan penyuluhan kesehatan, baik oleh petugas atau kegiatan penyuluhan yang dilakukan oleh mahasiswa yang sedang melakukan praktek kesehatan di daerah tersebut.

\section{Media Massa}

Akibat kemajuan dunia telekomunikasi dan informasi, maka orang tua dan anak usia remaja menggunakan sarana itu utuk memperoleh informasi menggunakan media massa, seperti radio, televisi dan internet, jadi orang tua yang melek dengan dunia maya, tidak merasa kesulitan dalam mengakses informasi tentang kesehatan.

\section{Peran orang tua dalam memberikan informasi kesehatan reproduksi remaja tersebut di Kabupaten Lima Puluh Kota}

Keberadaan orang tua memiliki peran pentang dalam pendidikan kesehatan reproduksi pada anak remaja di Kabupaten Lima Puluh Kota. Keterlibatan orang tua telah ada sejak anak menginjak usia remaja, wujud dari keterlibatan orang tua dalam memberikan informasi kesehatan reproduksi. 


\section{Pemberi informasi pertama}

Sebenarnya informasi kesehatan reproduksi telah dilakukan oleh orang tua sebelum dan selama anak menginjak masa remaja, pemberian informasi dilakukan misalnya ketika anak menstruasi pertama, atau ada masalah seputar kesehatan reproduksi, anak perempuan biasanya terbuka pada ibunya dan ibu akan memberikan jawaban berdasarkan pengalaman yang mereka dapat dari sumber informasi, baik teman, petugas kesehatan atau melalui media massa atau dari guru mata pelajaran Biologi di sekolah.

\section{Mengawasi perkembangan kesehatan reproduksi anak}

Peran yang dimainkan oleh orang tua juga sebagai pihak yang mengawasi perubahan fisik dan perilaku pada anak. Peran ibu di Nagari Situjuh Banda Dalam telah ada ketika anak mereka tumbuh menjadi remaja. Orang tua senantiasa mewaspadai perubahan-perubahan fisik dan psikologis anak sebagai upaya untuk mencegah penyimpangan seksual anak. Ibu selalu berdiksui dan menjawab pertayaan dari anak tentang kesehatan reproduki yang mereka sampaikan.

\section{Strategi preventif untuk memberikan informasi kesehatan reproduksi pada remaja dalam mengatasi masalah kesehatan reproduksi}

Untuk itu dalam penelitian dirumuskan tiga upaya yang dipandang penting untuk membantu orang tua dalam sosialisasi pengetahuan kesehatan reproduksi remaja di Kabupaten Lima Puluh Kota, khususnya di Nagari Situjuh Banda Dalam. Ketiga strategi preventif tersebut adalah:

\section{Pendidikan kesehatan reproduksi oleh orang tua bermuatan nilai budaya lokal}

Salah satu strategi yang dimainkan oleh orang tua pada anak menggunakan simbolsimbol budaya lokal yang mengandung makna mendalam. Simbol budaya tersebut berupa simbol verbal dengan menggunakan bahasa lokal, diantaranya:

(1) bakecegak (bergurau), merupakan aktivitas bergurau dengan anak tapi tidak bersifat vulgar; hal ini dipandang tepat, biasanya dilakukan oleh seorang ayah pada anak lelakinya.

(2) orang tua menggunakan istilah lokal "padusi umpamo tolua" (perempuan ibarat telur), artinya perempuan anak lemah secara fisik dan mudah rusak karena salah dalam pergaulan. Selain itu juga digunakan istilah "padusi umpamo timun, laki-laki umpamo durian, makonyo timun jan mandakek ka durian" (perempuan ibarat buah ketimun dan laki-laki ibarat buah durian, makannya jangan timun dekat durian), karena mudah rusak atau dilukai oleh durian tersebut. Di samping itu untuk memberikan informasi dampak dari masalah kesehatan reproduksi orang tua juga menggunakan istilah dulu bajak dari kabau (dimaknai sebuah perilaku terlarang yang tidak lazim, karena melakukan hubungan seksual sebelum menikah secara syah menurut agama dan negara). Perilaku lain yang bermakna untuk mencegah masalah kesehatan reproduksi remaja orang tua selalu mengingatkan anak remaja bahwa jangan seperti perilaku anau mangaja sigai (diibaratkan perempuan yang mengejar laki-laki), seharusnya sigai yang mangaja anau (laki-laki yang mengejar perempuan).

\section{Integrasi materi pendidikan kesehatan reproduksi melalui media seni tradisional}

Media yang digunakan yaitu media seni drama dan seni musik tradisional, seperti (1) media seni randai; infomasi kesehatan reproduksi dimasukkan pada dialog antar pemain dan dendang randai tersebut, sehingga pesan atau informasi kesehatan reproduksi remaja secara tidak langsung tersampaikan oleh pemain kepada para penonton, selanjutnya melalui (2) media saluang: media ini merupakan media senik musik tradisional yang berisikan syairsyair informatif dan tentang kisah hidup, pesan dan cerita, tetapi di Nagari Situjuh Banda Dalam

\section{Buku saku kesehatan reproduksi untuk orang tua Berbasis budaya lokal}

Buku saku kesehatan reproduksi, merupakan media yang dipandang efektif dalam penelitian ini, karena banyak orang tua tidak memiliki pengetahuan yang cukup untuk 
memberikan informasi seputar masalah kesehatan reproduksi di Nagari Situjuh Banda Dalam. Faktor latar belakang pendidikan dan pekerjaan orang tua serta kedekatan orang tua dengan anak mempengaruhi keberhasilan penyampaian informasi kesehatan reproduksi remaja yang tepat atau terarah. Melalui buku saku kesehatan reproduksi yang bermuatan nilai-nilai budaya Minangkabau dapat dijadikan sumber informasi yang mudah dicerna oleh para orang tua. Berdasarkan Undang-undang No.7 Tahun 1984 tentang Konvensi Penghapusan Segala bentuk diskriminasi terhadap perempuan (CEDAW) tercantum hak-hak asasi. Dinyatakan juga bahwa berhak memperoleh penerangan edukatif yang berkaitan dengan hak reproduksinya, serta berhak memperoleh pelayanan kesehatan reproduksi. juga berhak memperoleh penerangan, pendidikan dan sarana-sarana yang berkaitan dengan hak reproduksi (pasal 16). Terkait dengan masalah penelitian ini telah ada upaya preventif orang tua di Nagari Situjuh Banda Dalam dalam mencegah masalah kesehatan reproduksi remaja. Strategi preventif untuk memberikan informasi kesehatan reproduksi pada remaja dalam mengatasi masalah kesehatan reproduksi, yaitu dengan cara; (a) Pendidikan kesehatan reproduksi oleh orang tua bermuatan nilai budaya lokal, (b) Integrasi materi pendidikan kesehatan reproduksi melalui media seni tradisional, dan (c) Buku saku kesehatan reproduksi untuk orang tua Berbasis budaya lokal.

\section{Penutup}

Sumber informasi sumber tentang kesehatan reproduksi remaja di Kabupaten Lima Puluh Kota adalah dari (a) orang terdekat, (b) penyuluhan kesehatan dan kader posyandu, serta (c) media massa. Peran orang tua dalam memberikan informasi kesehatan reproduksi remaja tersebut di Kabupaten Lima Puluh Kota adalah berperan dalam; (a) sebagai pemberi informasi pertama dan (b) mengawasi perkembangan kesehatan reproduksi anak. Strategi preventif untuk memberikan informasi kesehatan reproduksi pada remaja dalam mengatasi masalah kesehatan reproduksi, yaitu dengan cara; (a) Pendidikan kesehatan reproduksi oleh orang tua bermuatan nilai budaya lokal, (b) Integrasi materi pendidikan kesehatan reproduksi melalui media seni tradisional, dan (c) Buku saku kesehatan reproduksi untuk orang tua berbasis budaya lokal

\section{Daftar Pustaka}

Agustien, Aliv Via. (2014). Pengembangan Buku Saku Sebagai Bahan Ajar Akuntansi Pada Pokok Bahasan. Artikel dalam Jurnal Penyesuaian Perusahaan Jasa Kelas XI IPS SMA Negeri 18 Surabaya.

Ami, Sofan dan Ahmadi, LifKhoiru. (2010) Konstruksi Pengembangan pembelajaran. Jakarta: PT Prestasi Pustaka Raya

Departemen Kesehatan RI. (2008). Panduan Bahan Ajar Kesehatan. Jakarta: Depkes

Gunarsa, YSD. (2005). Asas-asas Psikologi Keluarga Idaman. Jakarta: PT BPK Gunung Mulia.

http://www.hidayatjayagiri.net/2013/01/memahami-fungsidan-peran-orang-tua/html. Diakses tanggal 7 Maret 2016

https://www.k4health.org/toolkits/indonesia/program-program-kesehatan-reproduksi-remaja. diakses tanggal 6 Maret, 2016.

https://septiancahyosusilo.wordpress.com, diakses tanggal 7 Maret 2016

ICPD. (2014). International Conference on Population and Development Programme of Action. United Nations: UNFPA 